\title{
THE FIRST MOSCOW FREE PUBLIC LIBRARY AND ITS CREATOR ALEXANDER D. CHERTKOV ${ }^{1}$
}

\begin{abstract}
:
The article deals with the history of a unique book and manuscript collection by the famous historian, numismatist and Slavicist, A.D. Chertkov (1789-1858). The collection later became the first free private library in Moscow. Special attention is given to the development of Chertkov's love of books and bibliophilia, the emergence of his idea to collect all works in every language about Russia in a library. Interest in the history and culture of the Slavs was reflected not only in his academic work, but also in the composition of his collection, which included books in Slavic languages. The article reveals the contribution of Chertkov to Russian book culture.
\end{abstract}

\section{Keywords:}

A.D. Chertkov, book culture of Russia, Chertkov Library, M.P. Pogodin, G.A. Chertkov, P.I. Bartenev.

АННОТаЦИЯ: М.М. ФРОЛОВА. «ПЕРВАЯ БЕСПЛАТНАЯ ПУБЛИЧНАЯ БИБЛИОТЕКА В МОСКВЕ И ЕЕ СОЗДАТЕЛЬ АЛЕКСАНДР Д. ЧЕРТКОВ».

В статье рассматривается история создания известным историком, нумизматом, славистом А.Д. Чертковым (1789-1858) уникального книжного и рукописного собрания, которое впоследствии стало первой в Москве бесплатной частной библиотекой. Обращается особое внимание на возникновение у Черткова любви к книге, библиофильству и появление замысла - собрать в библиотеке все сочинения и на всех языках о России. Интерес к истории и культуре славян отразился не только в научном творчестве ученого, но и на составе его коллекции, в которую вошли книги на славянских языках. Раскрывается вклад Черткова в книжную культуру России.

\section{Ключевые слова:}

А.Д. Чертков, книжная культура России, Чертковская библиотека, М.П. Погодин, Г.А. Чертков, П.И. Бартенев.

A lexander Dmitrievich Chertkov (1789-1858) was bibliophile, bibliograApher, scholar, historian, corresponding member of the Academy of Sciences, creator of the first free public library and museum in Moscow. He was elected a member of the Imperial Society of History and Russian Antiquities.

He was born into a family of book lovers and began to collect his personal library from a young age. Wars with Napoleon and foreign campaigns, in which Chertkov participated with the rank of a Leibe Guards of the Horse Regiment lieutenant, awakened Russian society's interest in Russian history. Bibliophilia

\footnotetext{
1 The work was carried out with the financial support of the RFBR (grant № 18-512-76004).
} 
came into vogue. In 1817, in the journal "Son of the Fatherland," the corresponding member of the Academy of Sciences Friedrich von Adelung put forward the idea of creating a Russian national museum, which would include a national library. The latter was to contain a complete, systematic collection of all books in Russian and foreign languages about Russia, and this task was to be fulfilled by the state. Similarly, the Director of the Imperial Public Library in St. Petersburg, Alexey Olenin, also proposed to develop the Imperial Public Library, expressing his intention in a private letter earlier in December 1815. Other progressive sons of the Fatherland expressed similar thoughts.

This large-scale project also captivated Chertkov, which he wrote about in 1838 in the preface to the catalog "The General Library of Russia", outlining his patriotic plan. Prior to Chertkov,

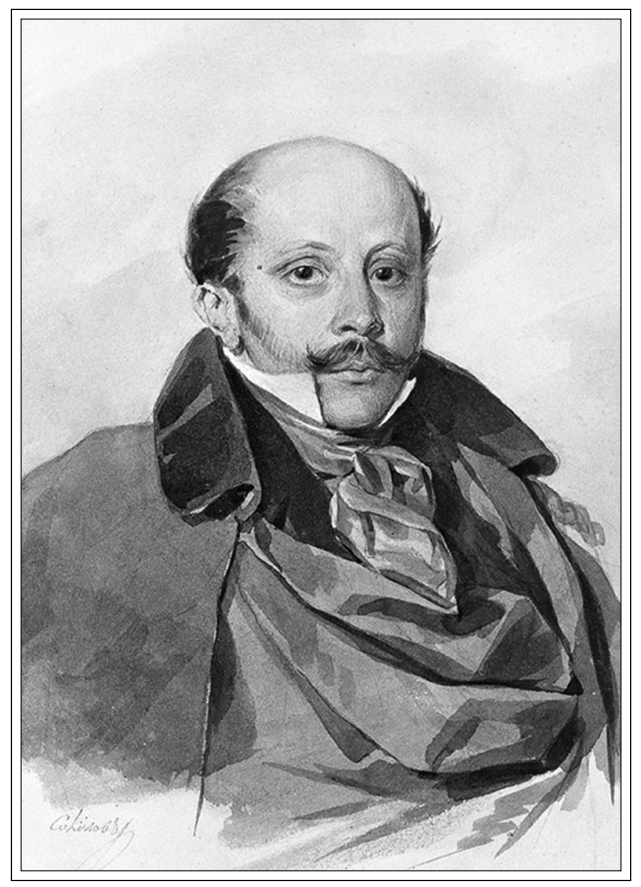

Alexander Dmitrievich Chertkov.

Artist P.F. Sokolov, the end of 1830 s no one in the country had tried to implement such a grandiose enterprise: neither the state nor private individuals. Chertkov belonged to the best segment of the nobility, which felt itself to be a transformer of the Fatherland. This young man began to create a huge library on his own. It was quickly replenished with numerous books and manuscripts, including quite rare ones. For example, it included the 1516 edition of the Russian Chronograph, which Chertkov purchased in 1817 from a private individual in St. Petersburg. He had sufficient energy and financial opportunities but often doubted that his plan would be successfully implemented. Meanwhile, the number of books in his library grew with each year, giving the collector greater confidence in the feasibility of achieving his goal.

Chertkov's contemporaries gradually began to recognize the uniqueness of his library. It was praised by the historian and bibliographer Ivan Sakharov in a letter to Chertkov from St. Petersburg in 1841. The famous historian Mikhail Pogodin, in the journal Moskvityanin, stressed that the most complete collection of books about Russia belonged not to the Russian Academy nor to any university or scientific community, but was in Chertkov's library. There was even an article published about it in Leipzig. The uniqueness of Chertkov's library consisted not only in the composition of its book and manuscript treasures but also in the fact that Chertkov himself participated in the acquisition of the collections, 
in addition to engaging commission agents and book sellers. Chertkov devoted considerable energy to this business, personally looking for suitable books and manuscripts in book markets and stores in Russia and Western Europe. He was an educated person with an encyclopedic knowledge and constantly increased his erudition by familiarizing himself with the contents of each book he acquired. Moreover, Chertkov compiled annotations on them, which were then included in his printed "Second Addition" to his library's catalog. These annotations were greatly appreciated by the collector's contemporaries. The rector of St. Petersburg University, academic Peter Pletnyov, wrote that by reading them one could become a scholar, or at least a well-read person.

Chertkov's love of books and manuscripts was passed on to his descendants. After the death of the collector, his son Gregory did not sell the collected treasures at the book auction; fulfilling his father's will, he built a magnificent building for the library and opened it in 1863. Peter Bartenev, a great lover and connoisseur of Russian history of the 18th-19th centuries and a tireless bibliographer who gave the library a second life, was invited to the post of its director. He widely published information about the library's manuscript treasures in the journal "Russian Archive," which began to be published at the library. Numerous gifts with the autographs of donors and authors began arriving in the collections of the Chertkov library. Scholars considered it an honor to submit their manuscript or book here. All of this attested to the transformation of this repository into one of the main centers of book culture in Russia.

The private collections of the admiral of the Russian Empire, Count Alexey Musin-Pushkin, were donated to the library, as well as of Russian writer and prince Vladimir F. Odoyevsky, Acting State Councilor and Director of the Imperial Public Library Baron Modest A. Korf, major general and military historian Ivan P. Liprandy and many other famous people. In 1864 it was enriched with a priceless notebook containing the handwritten texts of the famous Russian poet Mikhail Lermontov. The motive behind these gifts was the idea that unique collections should not belong to a private person but to the Fatherland. Confidence in the durability and reliability of the Chertkov library also played an important role.

The library gradually gained fame and turned into a vivid manifestation of the cultural life of pre-revolutionary Moscow. It was

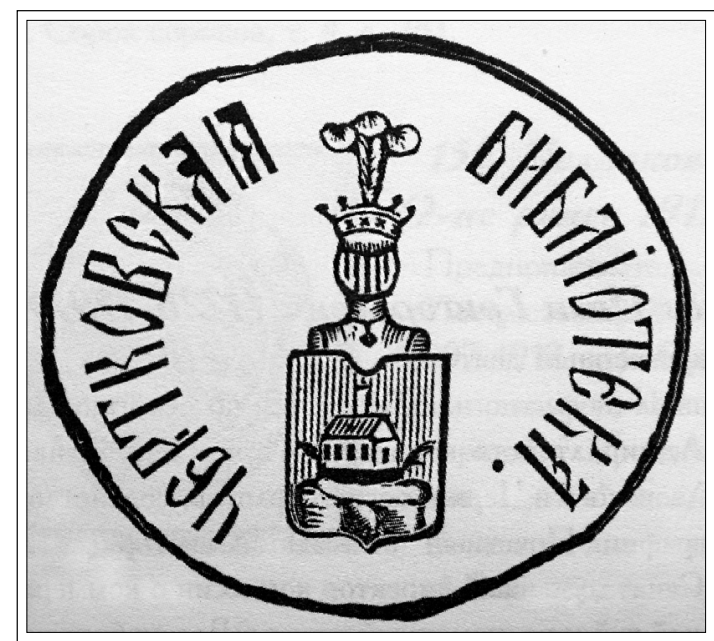

Ex libris of Alexander D. Chertkov 
visited not only by Muscovites and the residents of other Russian cities, but also by foreigners. Such famous writers and scholars as the poet Vasily Zhukovsky worked in it, as did writer Leo Tolstoy, folklorist Peter Bessonov, philosopherfuturologist, teacher and bibliographer Nikolay Fyodorovich Fyodorov and many other outstanding personalities. In addition to books, manuscripts, maps and graphic materials, the library of Chertkov contained valuable collections of antique and Russian coins, ancient Russian and Egyptian antiquities, painted Etruscan vases and mirrors, natural science collections of minerals, insects, butterflies and herbaria. Thus, it played the role of not just a library but also of a free, public museum.

In 1871 Chertkov's son Gregory donated this library (over 10,500 books and brochures) with all its collections to Moscow. It was first located in the building of the Moscow Public and Rumyantsev Museums. Then it formed the basis of the library of the Historical Museum (in 1887). In 1938 the main book holdings were transferred to the newly created State Public Historical Library. The principle of the indivisibility of the collection, stated when it was bequeathed to the Moscow library, was constantly violated. The most valuable manuscripts, letters and ancient books were included in the Department of Manuscripts of the Historical Museum, all the archival material - in the Department of Written Sources, manuscripts of writers of the 18th-19th centuries were transferred to the State Literary Museum of Moscow.

In the 1830s-40s Chertkov published General Library of Russia or a catalog of books for studying our country in all respects and details and The Second Addition to it. The catalog consisted of 4701 book titles. The academics Peter Köppen, Yakov Berednikov and Izmail Sreznevsky considered the Chertkov library "a good gift to the Fatherland," "a diamond shining with European distinctiveness," "the foundation of Russian bibliography" and one of its main sources.

Chertkov was also preparing another special catalog, which was to include handwritten and printed letters, atlases and maps of Russia and its regions, plans and views of cities, monasteries, churches, villages, monuments erected in honor of Russian victories; the plans of battles and sieges, the positions of the Russian army and fortresses captured by the Russians, images of historical events, types of battles, samples of uniforms of troops, images of the clothing of people living within its territory, antiquities and everything related to Russia. This is evident from his introduction to the catalog of 1845 , but death prevented him from carrying out his creative plan.

Among other things, the Chertkov library included books by Slavic authors of the period of the national revival (18th-19th centuries). Bibliographer Nina Mikhailovna Pashaeva searched the holdings of the State Public Historical Library for books preserved in many Slavic languages and published the corresponding catalog. There were books in the Chertkov library in the Bulgarian, Polish, Czech and Serbo-Croatian languages. Croatian glagolitic books are especially interesting, and they, like many other publications, have found their 
way into other collections and libraries. They are yet to be identified by scholars and book sellers.

The composition of Chertkov's personal (home) library, reflecting the interests of its owner, remains hypothetical. It undoubtedly contained books of an entertaining nature in foreign languages, Masonic literature, books on the military art of European states, publications on history, numismatics and art. Of course, it also contained books on the geography and economy of Western European countries and guides to cities and museums in Europe. Reconstruction of this composition is the task of researchers.

Among other things, Chertkov was a scholar, having published at his own expense a number of academic monographs. A vivid illustration of this is his book Memoirs of Sicily, published in Moscow in 1835. It gave the Russian reader an idea of this wonderful island, its ancient temples, caves, nature and the poverty of its inhabitants at that time. This work received the well-deserved and unanimous praise from its reviewers, but all of them noted the poor quality of the illustrations (due to imperfections in the lithography). This shortcoming was overcome in the The Third Addition (Moscow, 1842), in which Chertkov described and presented images of 60 coins: copper, silver and gold of the "tsar period." Usually the scholar printed his books in two versions. One version was intended for sale to the general public and was published on cheap Russian paper. The other version was a "gift": it was printed on English Whatman paper, had a gold edge and morocco binding. Two of Chertkov's books were especially luxuriously published. One was a translation of the Chronicles of Constantine Manasses from Greek into Slavic (which was accompanied by an essay on the history of the Bulgarians), published in Moscow in 1842. The second book was a description of the war of Prince Svyatoslav against the Bulgarians and Greeks in 967-71, published the following year.

In total, Chertkov published 18 of his books, which were distinguished by amazing typographic skills. According to contemporaries, these books were true cultural monuments of their time. They also had high academic value: for his research on numismatics, for example, he received the Demidov Prize, which he donated entirely towards the publication of the oldest Russian dated book, the Gospel of Ostromir 1056-57.

Thus, Chertkov made a very noticeable and significant contribution to the book culture of Russia at that time. He acted simultaneously as a collector of a remarkable library, a compiler of its catalog ("The General Library of Russia"), and a publisher of his own research. He opened the first free, public library in Moscow. The scale of his cultural activity has not yet been fully appreciated and still awaits its researchers. 


\section{BIBLIOGRAPHY}

Frolova M.M. Alexander Dmitrievich Chertkov (1789-1858). Moscow, 2007. 589 p.

Pashayeva N.M. Slavyanskaya kniga epokhi natsional'nogo vozrozhdeniya (konets XVIII v. - 1878 g.) v fondakh GPIB Rossii: Bolgariya. Galichina. Zakarpat'ye. Bukovina. Luzhitskiye serby. Sloveniya. Khorvatiya. Moscow: Izd-vo Gosudarstvennoj publichnoj istoricheskoj biblioteki Rossii, 2012. 124 p.

\section{ILLUSTRATIONS}

1. Alexander D. Chertkov in the ceremonial uniform of the Leibe guards Horse regiment. Artist P.E. Rockstuhl. Moscow, State Historical Museum, 1820 s.

2. Alexander D. Chertkov. Artist P.F. Sokolov, the end of 1830 s.

3. Alexander D. Chertkov. Artist S.K. Zaryanko, 1857.

4. Diploma on the introduction of A.D. Chertkov in the Noble genealogy book of the Moscow province. Department of written sources of the State Historical Museum, 1833.

5. Chertkov Gregory Alexandrovich, 1860-63.

6. G.A. Chertkov's mansion. Left wing of Chertkov's library. Engraving by an unknown artist, 1860 s.

7. G.A. Chertkov's mansion. 7 Myasnitskaya str., Moscow.

8. Ex libris of Alexander D. Chertkov.

9. Half title of A.D. Chertkov's book "Description of the Russian coins." Moscow, 1834.

10. The title page of A.D. Chertkov's book "Description of the Russian coins." Moscow, 1834.

11. The title page of A.D. Chertkov's book "On the translation of the Chronicles by Constantine Manasses from Greek into Slavic on two manuscripts: the Vatican and the Patriarchal libraries with an essay on the history of the Bulgarians." Moscow, 1842.

12. Half title of A.D. Chertkov's book "Description of the war of Prince Svyatoslav against the Bulgarians and Greeks in 967-71." Moscow, 1843.

13. The title page of A.D. Chertkov's book "Description of the war of Prince Svyatoslav against the Bulgarians and Greeks in 967-71.” Moscow, 1843. 